THE INDIGNANT GENERATION 



\title{
THE INDIGNANT GENERATION
}

\author{
A Narrative History of African American \\ Writers and Critics, 1934-1960
}

Lawrence P. Jackson 
Copyright $(9) 2011$ by Princeton University Press

Published by Princeton University Press, 41 William Street, Princeton, New Jersey 08540

In the United Kingdom: Princeton University Press, 6 Oxford Street, Woodstock,

Oxfordshire OX20 1TW

press.princeton.edu

All Rights Reserved

Fourth printing, and first paperback printing, 2013

Paperback ISBN 978-0-691-15789-4

The Library of Congress has cataloged the cloth edition of this book as follows Jackson, Lawrence Patrick.

The indignant generation : a narrative history of African American writers and critics, 1934-1960 / Lawrence P. Jackson.

p. $\mathrm{cm}$.

ISBN 978-0-691-14135-0 (cloth : alk. paper) 1. American literature-African American authors-History and criticism. 2. African Americans-Intellectual life-20th century. 3. African American critics. 4. African Americans-Race identity. 5. African American arts-20th century. I. Title.

PS153.N5J37 2010

810.9'896073-dc22 2009049322

Includes bibliographical references and index.

The following publications and publishers have given permission to reproduce portions of previously published materials: "A History of African American Literary Critics from 1900-1960," Cambridge Companion to African American Literature, ed. Jerry Ward and Maryemma Graham (New York: Cambridge University Press, forthcoming); “The Irredeemable Promise: J. Saunders Redding and Negro New Liberalism," American Literary History (Fall 2007), 712-44; "Bucklin Moon and Thomas Sancton: Crusaders for the Liberal Left," Southern Literary Journal (Fall 2007), 76-97; "The Aftermath: The Harlem Renaissance Twenty Years Later," Cambridge Companion to the Harlem Renaissance, ed. George Hutchinson (New York: Cambridge University Press, 2007), 239-53; "Ralph Ellison's Integrationist Politics," Oxford Historical Guide to Ralph Ellison, ed. Steve Tracy (New York: Oxford University Press, 2004), 171-205. “The Bean Eaters" by Gwendolyn Brooks is reprinted courtesy of Brooks Permissions.

British Library Cataloging-in-Publication Data is available

Publication of this book has been aided by Furthermore: a program of the J. M. Kaplan Fund. This book has been composed in Minion Pro text with Bodoni Std Poster display Printed on acid-free paper. $\infty$ Printed in the United States of America 109876554 


\author{
For My Parents \\ Verna Mitchell Jackson \\ and \\ Nathaniel Jackson Jr. (1932-1990) \\ And the long black and tan line
}

$\begin{array}{ll}\text { Charles Dugger } & \text { Emmanuel Blow } \\ \text { Harold Macklin } & \text { Webster Claiborne } \\ \text { Wilbur Macklin } & \text { Milton Allen } \\ \text { Danbridge Macklin } & \text { Stuart Simms } \\ \text { Roland Dougherty, Sr. } & \text { Edward Rosemond } \\ \text { Raymond Mitchell } & \text { Bruce Hodge } \\ \text { Roy Borom } & \text { Franklin Beard } \\ \text { Donald Rigby } & \text { John Murphy } \\ \text { Victor Dates } & \text { Ralph Doram } \\ \text { John James } & \text { Prentiss Nolan } \\ \text { Ernest Colvin } & \text { Bruce Edemy } \\ \text { Edward Anderson } & \text { Dr. Eugene Ford } \\ \text { Otis Washington } & \text { George Barrick } \\ \text { Walter Gray II } & \text { Harcourt Brace } \\ \text { Donald Smith } & \text { Arthur Harris } \\ \text { Peter Miller, Sr. } & \text { Chester Lovett } \\ \text { Raymond Harcum } & \text { Cyrus Marshall } \\ \text { Percy Johnson } & \text { Howard Rawlings } \\ & \text { and }\end{array}$


